J-DEPACE, Volume. 2, Nomor. 1, Juni 2019, Hal 103 - 111

Tersedia online di :http://jurnal.lpmiunvic.ac.id/index.php/jpkm

\title{
KEPEDULIAN TERHADAP LINGKUNGAN : PENANAMAN BIBIT POHON DI TAMAN WISATA ALAM (TWA) KOTA SORONG PROVINSI PAPUA BARAT
}

\author{
Lanny Wattimena, Amatus Turot, Maya Pattiwael, \\ Charliany Hetharia, Yerrynaldo Loppies \\ Fakultas Ilmu Pertanian dan Lingkungan, Universitas Victory Sorong \\ email: lannywattimena@gmail.com
}

\begin{abstract}
ABSTRAK
Salah satu langkahyang dilakukan untuk meningkatkan rasa kepedulian terhadap lingkungan adalah dengan melakukan penanamanbibit pohon. Penanaman dilakukan di Taman Wisata Alam (TWA) Sorong.Pemilihan lokasi didasarkan pada kondisi kawasan tersebut yang mengalami kerusakan akibat ulah manusiadiantaranya yaitu alih fungsi lahan menjadi perkebunan bahkan pemukiman masyarakat.Aktivitas tersebut tentu saja memberikan dampak negatif bagi lingkungan sekitar.Kegiatan yang dilaksanakan padatanggal 26 Mei 2018ini melibatkan Civitas Akademika UNVIC Sorong dan pihak Balai Besar Konservasi Sumber Daya Alam (KSDA) Papua Baratdengan menanam jenis pohon Agathis, Durian, Rambutan dan Mahoni yang secara keseluruhan berjumlah 200 bibit pohon.Tanggung jawab pemeliharaan dari tanaman ini merupakan tanggung jawab bersama antara Fakultas Ilmu Pertanian dan lingkungan UNVIC Sorong dengan pihak Balai Besar KSDA Papua Barat. Kegiatan ini diharapkan dapat meningkatkan kesadaran masyarakat Kota Sorong akan pentingnya menjaga dan melestarikan hutan khususnya di kawasan Taman Wisata Alam.
\end{abstract}

Kata Kunci : Penanaman, Bibit Pohon, Lingkungan

\begin{abstract}
One of the steps taken to increase awareness of the environment is by planting tree seeds. Planting is carried out in the Sorong Nature Tourism Park (TWA). The choice of location based on the condition of the area which has been damaged by human activities, including the conversion of land into plantations and even community settlements. These activities certainly harm the surrounding environment. The event which held on May 26, 2018, involved the UNVIC Academic Community of Sorong and the West Papua Center for Natural Resources Conservation (KSDA) by planting Agathis, Durian, Rambutan and Mahogany trees, totalling 200 tree seedlings. The maintenance responsibility of this plant is a shared responsibility between the Faculty of Agriculture and the environment of UNVIC Sorong with the West Papua Regional Office of the KSDA. This activity is expected to increase the awareness of the people of Sorong City on the importance of maintaining and preserving forests, especially in the Nature Tourism Park area.
\end{abstract}

Keywords: Planting, Tree Seeds, Environment 


\section{PENDAHULUAN}

Semakin banyaknya pembangunan gedung danmeningkatnya jumlah kendaraan, secara otomatis akan mempengaruhi peningkatan temperatur udara di wilayah tersebut. Polusi udara tak terhindarkan, ruang terbuka hijau makin terdesak.Salah satu dampak negatif dari tercemarnya lingkungan hidup yang dialami oleh manusia di bumi ini adalah terjadinya pemanasan global dan perubahan iklim.Untuk mengurangi efek pemanasan global dan perubahan iklim adalah dengan memperbanyak pohon melalui kegiatan penanaman.Oleh sebab itu, diperlukan upaya dari berbagai pihak untuk menjaga dan melestarikan bumi sebagai bentuk kepedulian terhadap lingkungan (Ihsantika, 2013).

Penanamanpohon memiliki manfaat bagi kelangsungan hidup berbagai makhluk hidup yang ada.Pesatnya pembangunan menyebabkan banyak pohon yang ditebang.Dengan denikian panas bumi meningkat serta jumlah pasokan air dalam tanah semakin berkurang.Oleh karena itu,dengan menanam pohon di sekitar perkotaan dapat menyerap polutan tertentu dan menyaring debu yang banyak kita temukan di udara Kota Sorong.Dengan demikian kita harus bersinergi, berbagi peran untukmenjaga bumi kita tetap lestari.Menanam pohon berarti kita telah mengimplementasikan caramenata lingkungan yang baik, dan menyelamatkan sumber air, serta mempertahankan udara bersih.

Salah satu langkahyang dilakukan untuk meningkatkan rasa kepedulian terhadap lingkungan adalah dengan menjadi sukarelawan untuk penanamanbibit pohon di Taman Wisata Alam (TWA) Sorong. Tanaman yang terdapat di TWA Sorongakan memberikan kontribusi yang cukup penting untuk sirkulasi udara yang segar dan bersih bagi masyarakat yang ada disekitar kawasan dan manfaat yang baik tentunya bagi masyarakat Kota Sorong. Penanaman bibit pohon yang dilakukan dilakukan ini untuk memperingati Dies Natalis Universitas Victory(UNVIC) Sorong, yang melibatkan Civitas Akademika UNVIC Sorong dan pihak Balai Besar Konservasi Sumber Daya Alam (KSDA) Papua Barat, sehingga diharapkan dengan adanya kegiatan ini berarti kita telah berpartisipasi dalam mendukung upaya penyelamatan bumi secara global.

\section{MASALAH}

Taman Wisata Alam sudah seharusnya menjadi kawasan yang dilindungi.Namun ada saja masyarakat yang menyalagunakannya.Berbagai aktivitas masyarakat seringkali 
merusak kawasan tersebut, diantaranya yaitu alih fungsi lahan menjadi perkebunan bahkanpemukiman masyarakat.Aktivitas tersebut tentu saja memberikan dampak negatif bagi lingkungan sekitar.Berdasarkan permasalahan tersebut, maka menjelang perayaan Dies Natalis UNVIC Sorong ini, dilakukan kegaiatan penanaman sebagai bentuk kepedulian terhadap lingkungankhususnya di Taman Wisata Alam Kota Sorong.

\section{METODE}

Metode yang digunakan pada kegiatan ini adalah pendidikan masyarakat yang bertujuan untuk meningkatkan pemahaman dan kesadaran masyarakat akan pentingnya kegiatan penanaman guna menjaga dan melestarikan hutan khusunya di kawasan Taman Wisata Alam.Penanaman pohon dilakukan pada hari sabtu tanggal 26 Mei 2018 dan berlokasi di kawasan Taman Wisata Alam (TWA) Km.14 Kota Sorong.

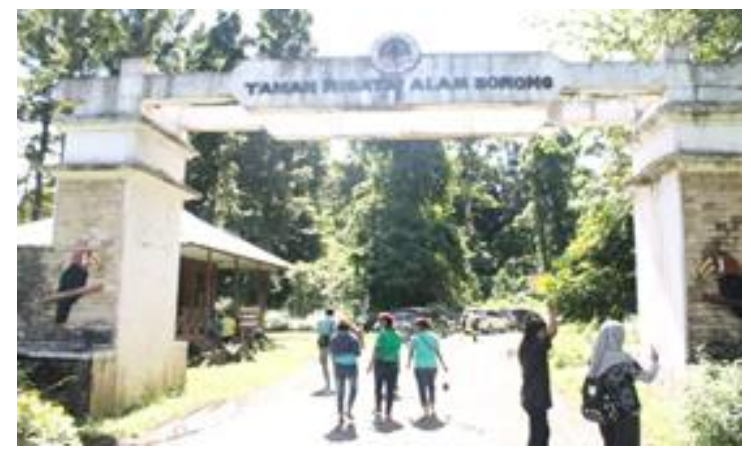

Gambar 1. Lokasi Penanaman Bibit Pohon(TWA Kota Sorong)

\section{PEMBAHASAN}

\section{a. Pemilihan Jenis Pohon}

Salah satu aspek penting yangperlu mendapatkan perhatian dalam rencana penanaman pohon adalah ketersediaan jenis tanaman yang akan ditanam. Penanaman yang dilakukan ini adalah di dalam kawasan hutan sehingga dapat dikatakan sebagai kegiatan reboisasi.Oleh karena itu, pemilihan jenis pohon harus berdasarkan pada kriteria yang ada. Menurut Indriyanto (2008), faktor yang perlu dipertimbangkan berupa faktor ekologi jenis pohon, ekonomi, sosial serta waktu untuk mencapai hasil yang diinginkan.Jenis tanaman yang dimaksud harus memenuhi persyaratan sebagai berikut (Ruslan, 1992 dalam Budi, 2006):

1. Persyaratan tempat tumbuhnya sesuai dengan kondisi tempat tumbuh pada lahan yang disediakan. 
2. Mengetahui teknik budidaya tanaman tersebut.

3. Bibit atau bahan tanamannya mudah disediakan.

4. Pohon dapat cepat tumbuh

Selain persyaratan yang disebutkan diatas, ada pula persyaratan tentang kemampuan pohon atau tanaman untuk tumbuh di tempat terbuka di bawah sinar matahari penuh.Pohon yang cepat tumbuh berarti mampu bersaing dengan alang-alang dan gulma lainnya.

Adapun jenis bibit yang ditanam pada kegiatan penanaman pohon adalah:

1. Damar (Agathis dammara) sebanyak 50 batang.

2. Durian (Durio zibethinus) sebanyak 50 batang.

3. Rambutan (Nephelium lappaceum) sebanyak 50 batang.

4. Mahoni (Swietenia mahagoni) sebanyak 50 batang.

Jenis-jenis bibit pohon tersebut diperoleh dari kelompok masyarakat asuhan dari Balai Besar KSDA Papua Barat yang merupakan mitra kerjasama dari Fakultas Ilmu Pertanian dan Lingkungan Universitas Victory Sorong, khususnya Program Studi Kehutanan.

\section{b. Pembuatan Lubang Tanam}

Pembuatan lubang tanam dilakukan 1 (satu) minggu sebelum kegiatan penanaman yaitu pada hari sabtu tanggal 19 Mei 2018.Pembuatan lubang tanam dilakukan pada lokasi yang sudah ditentukan oleh Tim pengawas TWA Sorong yang merupakan lingkup kerja dari Balai Besar KSDA Papua Barat.Beberapa faktor yang mempengaruhi penentuan jarak tanam yakni tingkat kesuburan tanah, jenis tanaman dan tingkat kemiringan lahan. Pada tanah yang subur, jarak tanam biasanya lebih besar jika dibandingkan pada tanah yang kurang subur.Jenis tanaman yang bertajuk lebar ditanam dengan jarak yang lebih besar, dibandingkan dengan jenis tanaman yang bertajuk kecil (Sri, 2006).Jarak tanam antar lubang tanam pada saat penanaman adalah 5 m.Ukuran kedalaman lubang tanam pada saat kegiatan penanaman adalah20-25 cm.Sebelum pembuatan lubang tanam, dilakukan kegiatan pembersihan lapangan. Kegiatan ini mutlak diperlukan dalam persiapan pembuatan tanaman hutan. Kegiatan pembersihan lapangan meliputi pembersihan semak, perdu dan pohon-pohon sisa.Pada saat kegiatan pembersihan lahan dilakukan, bahan-bahan yang dapat digunakan untuk 
membuat ajir dapat dikumpulkan.Pemasangan ajir dilakukan setelah pembersihan lahan (Perhutani, 1996).

Pengangkutan bibit dilakukan setelah pemasangan ajir, serta dilakukan secara hati-hati agar tidak mengalami kerusakan. Bibit yang ditanam adalah bibit yang sehat dan segar. Jarak antara lokasi penanaman dengan persemaian (tempat pembudidayaan bibit pohon) hanya berjarak 20 meter karena lokasi penanaman merupakan areal tinggal kelompok masyarakat asuhan dari Balai Besar KSDA Papua Barat, sehingga tidak memerlukan transportasi untuk pengangkutan bibit.

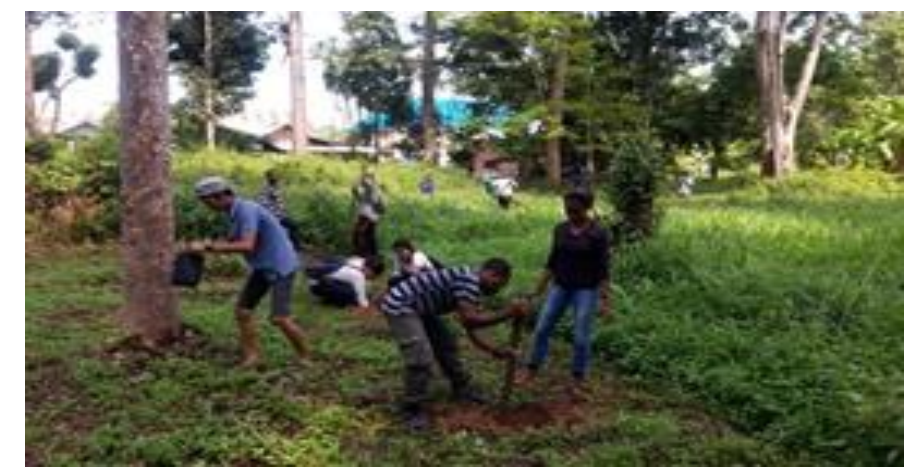

Gambar 2.Pembuatan Lubang Untuk Penanaman Bibit Pohon

\section{c. Pelaksanaan PenanamanPohon}

Kegiatan penanaman merupakan salah satu cara kepedulian kita terhadap lingkungan.Menurut Pattiwael (2018), penanaman bibit pohon merupakan salah satu bagian dari upaya konservasi. Kegiatan Penanaman Bibit Pohon dalam rangka menyongsong acara Dies Natalis UNVIC Sorong dan merupakan implementasi salah satu program hasil kerjasama Fakultas Ilmu Pertanian dan Lingkungan UNVIC Sorong Program Studi kehutanan dengan Balai Besar KSDA Papua Barat. Kerjasama antar kedua belah pihak berlangsung selama 5 tahun yaitu 2018-2022, dengan tujuan meningkatkan efektifitas pengelolaan kawasan konservsi di lingkup Balai Besar KSDA Papua Barat, meningkatkan kualitas pendidikan, penelitian dan pengabdian kepada masyarakat di Program Studi Kehutanan Fakultas Ilmu Pertanian dan Lingkungan Universitas Victory Sorong, serta meningkatkan sinergitas, peran dan tanggung jawab Pemerintah dan Perguruan Tinggi dalam upaya konservasi sumber daya alam dan ekosistemnya.

Kegiatan penanaman ini dilaksanakan di TWA Sorong pada hari Sabtu tanggal 26 Mei 2018 jam 08:00 WIT. Kegiatan inidihadiri oleh Civitas Akademika 
Universitas Victory Sorong (Dosen, staf dan mahasiswa), serta dari pihak Balai Besar KSDA Papua Barat.

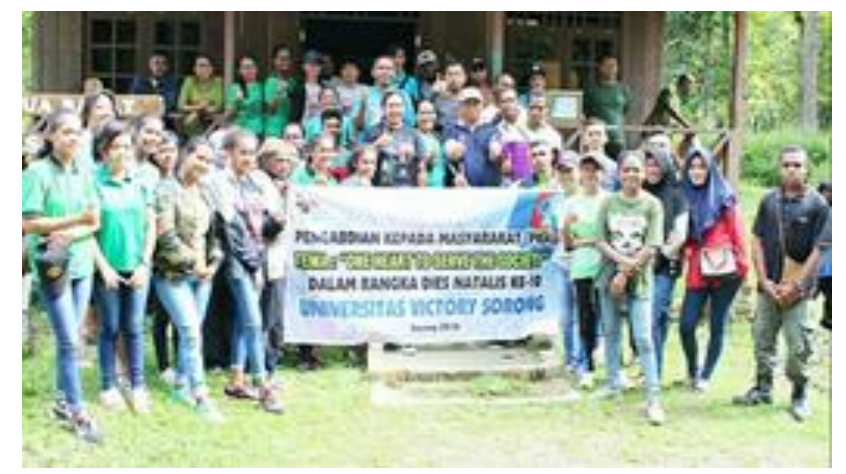

Gambar 3.Peserta Kegiatan Penanaman Bibit Pohon

Penanaman serentak ditandai dengan penyerahan bibit pohon dari pihak Universitas Victory Sorong kepada Balai Besar KSDA Papua Barat, dan penanaman pertamadilakukan oleh Kepala Tata Usaha Balai Besar KSDA Papua Barat, dalamkapasitannya mewakili Kepala Balai Besar KSDA Papua Barat yang tidak dapat hadir,sebagai tanda dimulainya penanaman oleh semua peserta.

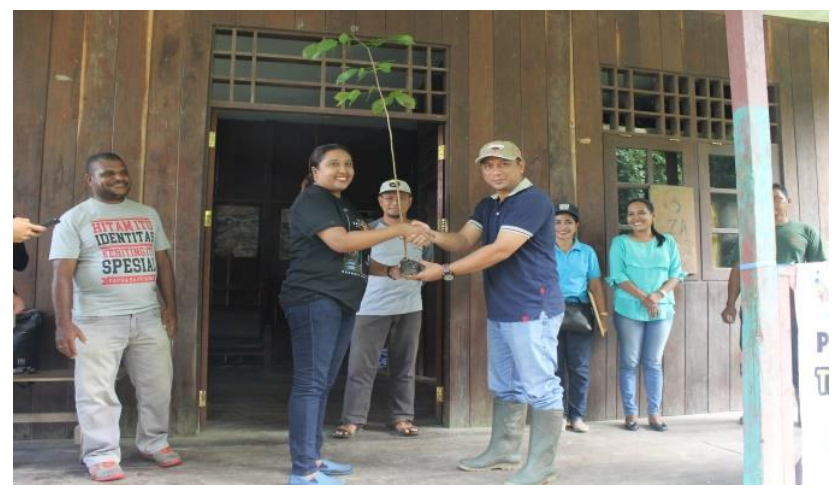

Gambar 4. Penyerahan Bibit Pohon

Bibit yang diperoleh berada dalampolybag. Oleh karena itu sebelum bibit ditanam, kantong plastik (polybag) dilepas dengan cara disobek. Sebelumnya media dipadatkan terlebih dahulu dengan cara memeras atau menekan polibag tersebut. Bibit diletakan di tengah lubang secara vertikal, terus ditimbun hati-hati dengan tanah. Dalam menimbun upayakan topsoil dimasukkan ke lubang terlebih dahulu. Kemudian tanah sekitar bibit dipadatkan dengan jalan ditekan secara hati-hati sampai terjadi kontak antara perakaran dengan tanah. 

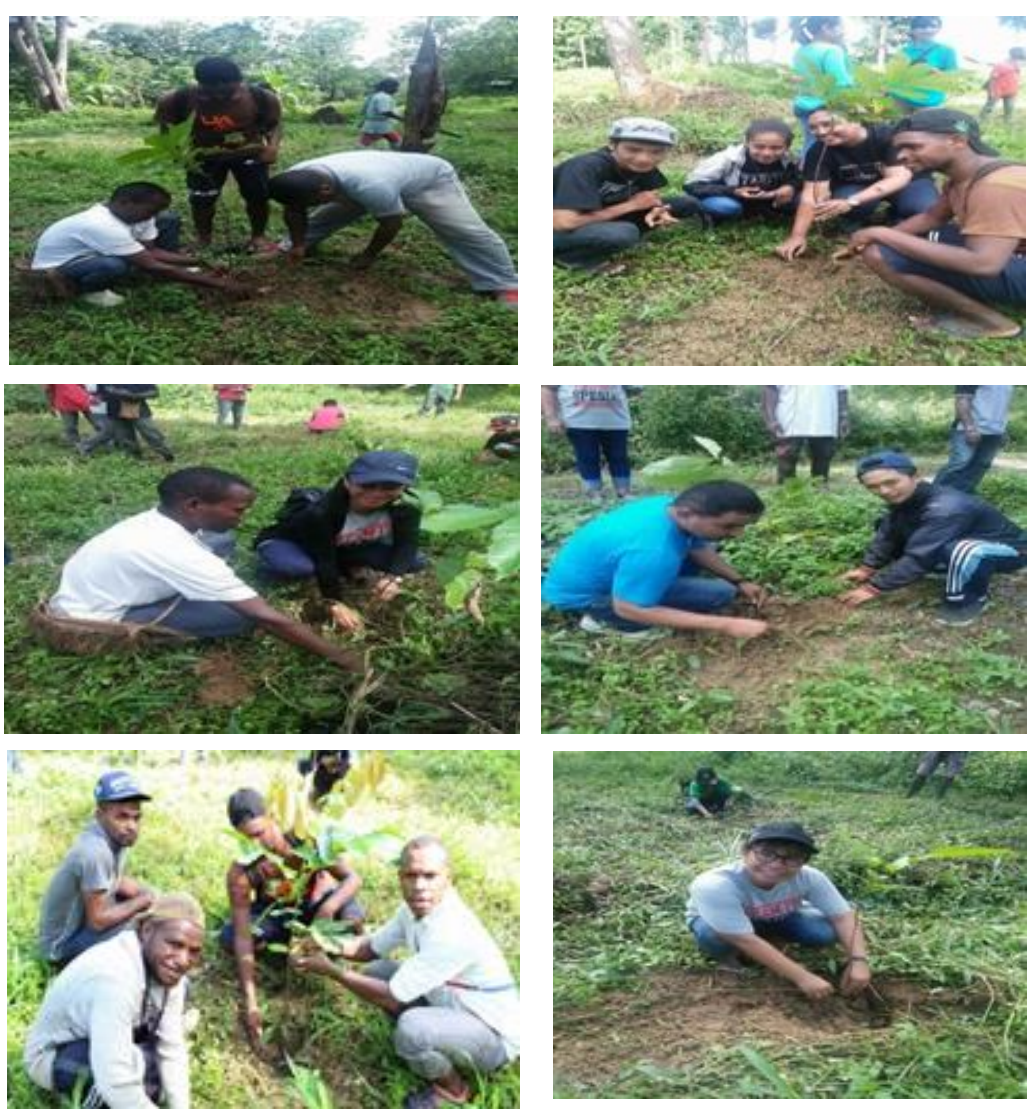

Gambar 5. Kegiatan Penanaman Bibit Pohon

Penanaman bibit pohon sebanyak 200 pohon ini jugadalam rangka mendukung program pemerintah melalui Pencanangan Penanaman 100 juta pohon berdasarkan Keputusan Presiden Indonesia Nomor 24 Tahun 2008, yang menyatakan bahwa bulan Desember merupakan Bulan Menanam Nasional, serta tanggal 28 Nopember 2008 ditetapkan sebagai Hari Menanam Pohon Indonesia, untuk program pemerintah di Tahun 2009, Presiden telah mencanangkan Program "ONE MAN ONE TREE", Satu Orang Menanam Satu Pohon.Penanaman pohon ini diharapkan dapat membantu meningkatkan kesadaran masyarakat Kota Sorong Propinsi Papua Baratakanpentingnya cinta lingkungan sebagai warga yang cinta Indonesia.Tanggung jawab pemeliharaan dari tanaman ini merupakan tanggung jawab bersama antara Fakultas Ilmu Pertanian dan lingkungan UNVIC Sorong dengan pihak Balai Besar KSDA Papua Barat.

\section{KESIMPULAN}

Penanaman bibit pohon yang dilakukanuntuk memperingati Dies Natalis Universitas Victory(UNVIC) Sorong, melibatkan Civitas Akademika UNVIC Sorong dan pihak Balai Besar Konservasi Sumber Daya Alam (KSDA) Papua Barat, dengan menanam serentak 
pohon Agathis, Durian, Rambutan dan Mahoni yang berjumlah 200 bibit pohon.Kegiatan ini dilaksanakan sebagai bentuk kepedulian lingkungan yang difokuskan pada Taman Wisata Alam Kota Sorong.

Pemilihan TWA Kota Sorong sebagai lokasi penanaman didasarkan pada kondisi kawasan tersebut yang mengalami kerusakan akibat ulah manusiadiantaranya yaitu alih fungsi lahan menjadi perkebunan bahkan pemukiman masyarakat.Aktivitas tersebut tentu saja memberikan dampak negatif bagi lingkungan sekitar.TWA seharusnya dilindungi dan dilestarikan karena dapat memberikan manfaat yang positif bukan hanya bagi masyarakat sekitar hutan tapi juga bagi masyarakat Kota Sorong secara keseluruhan.

Pelaksanaan penanaman ditandai dengan penanaman pertama yang dilakukan oleh Kepala Tata Usaha Balai Besar KSDA Papua Barat, dalamkapasitannya mewakili Kepala Balai Besar KSDA Papua Barat. Penanaman selanjutnya dilakukan oleh masing-masing peserta dengan mengikuti arahan yang disampaikan menyangkut tata cara penanaman.Tanggung jawab pemeliharaan dari tanaman ini merupakan tanggung jawab bersama antara Fakultas Ilmu Pertanian dan lingkungan UNVIC Sorong dengan pihak Balai Besar KSDA Papua Barat.Penanaman bibit pohon ini diharapkan dapat membantu meningkatkan kesadaran masyarakat Kota Sorong Propinsi Papua Baratakan pentingnya kegiatan penanaman guna menjaga dan melestarikan hutan khusunya di kawasan Taman Wisata Alam.

\section{DAFTAR PUSTAKA}

Ihsantika Aliya.Pentingnya Penghijauan di Kota. Kompasiana 23 Agustus 2013.

http://www.kompasiana.com/aliyasntka/pentingnya-penghijauan-dikota

(Tanggal akses20 April 2019)

Indriyanto. 2008. Pengantar Budidaya Hutan. PT Bumi Aksara. Jakarta

Pattiwael, M. 2018. Konsep Pengembangan Ekowisata Berbasis Konservasi Di Kampung

Malagufuk Kabupaten Sorong. Journal of Dedication to Papua Community (J-

DEPACE). Volume 1 Nomor 1 Desember 2018 Halaman 42-54

Perum Perhutani. 1996. Petunjuk Teknis (Prosedur Standar Operasional) Pembuatan

Tanaman Hutan.Perum Perhutani Unit III Jawa Barat.Biro Pembinaan Hutan. 
Sri Wilarso Budi R. 2006. Modul Pelatihan Penanaman Pohon.ITTO Project Participatory Establishment Collaborative Sustainable Forest Management In

Dusun Aro, Jambi.Serial Number : PD 210/03 Rev. 3 (F) Faculty Of Forestry IPB.

Sukoco Manik. Urgensi Pembentukan Kesadaran Pelestarian Lingkungan. Kompasiana.08 Februari 2017.

http://www.kompasiana.com/maniksukoco/urgensi-pembentukan-kesadaran pelestarian-lingkungan_(Tanggal akses10Mei 2019). 